\title{
Subversive Victims?
}

\section{The (non)Reporting of Sexual Violence against Male Victims During the War in Bosnia-Herzegovina}

\author{
Anette Bringedal Houge
}

\begin{abstract}
This article measures and evaluates the Norwegian newspaper Aftenposten's coverage of the extensive use of sexual violence during the war in Bosnia-Herzegovina, with a particular focus on sexual violence against men. According to an extensive report written by a UN Commission of Experts, the use of sexual violence against men as well as women was widespread and took place on all sides of the conflict. Yet what we heard about sexual violence in the media concerned women victims almost exclusively. The purpose of this study is to analyse the coverage with respect to gender from a feminist, critical constructivist perspective. The present argument is that the coverage of male victims is insufficient. According to the framework, this involves several constraints related to the power of dominant masculinity constructs and the social stigma attached to sexual violence, as well as some poor journalism, or lack of knowledge on the part of journalists.
\end{abstract}

Keywords: Bosnia, sexual violence, gender constructs, masculinities, peace journalism, content analysis

\section{Introduction}

During the war in Bosnia-Herzegovina, thousands of women were raped and sexually tortured as part of a war strategy to passivize, frustrate and demoralize the enemy and also to build a 'brotherhood of men' among allied soldiers and increase one's own population through forced pregnancies ${ }^{1}$. Public awareness of these war crimes was tremendous, and the mass media's continuous attention to the crimes and to the women victims of them probably helped put the Bosnian war on the international agenda and, further, illuminate and question a military tactic of extending the battlefield onto female bodies. As a response, several studies ${ }^{2}$ have been undertaken that deal with the extensive abuse of women during wartime, and the feminist stand that 'the personal is political' has received wider endorsement. Although these points mark the outset of this article, the focus of attention is on a rather unknown group of victims of sexual violence in war - men and boys.

According to the UN Commission of Experts' Final Report (CEFR) on the atrocities in Bosnia, sexual abuse was also, to a great extent, aimed at male prisoners at detention sites on all sides (see also Gutman 2001:x; Zarkov 2001:71). Why did the media 
fail to present these violations described in CEFR, when they generously unveiled and denounced the atrocities committed against women? One immediate and ungendered answer could be that these incidents must have been few and isolated, or at least that the extent to which this affected men must have been much smaller than the extent to which this affected women. And true, there was no pure all-male rape camps, as was the case for women. Nevertheless, these types of abuses and assaults were hardly uncommon and no less planned than were the assaults perpetrated against women. Further, the brutality of the sexual violence committed against men during the war in Bosnia fulfilled without a doubt the criteria underlying the infamous journalistic proverb 'if it bleeds it leads'.

The present article will suggest that the answer is indeed gendered, and that it has to do with masculinity constructs and a lack of gender sensitivity as well as some poor journalism. Thus, the analysis will be performed within a framework of critical constructivism, feminism and peace journalism, and the question the following pages will attempt to answer is: How and to what extent did the Norwegian newspaper Aftenposten's coverage of the sexual violence perpetrated during the war in BosniaHerzegovina encompass male victims?

\section{Structure of the Article}

The article begins with a presentation of background literature on sexual assaults and the war in Bosnia-Herzegovina, followed by a presentation of the analytical and theoretical framework in which the research question will be addressed. Accordingly, the methodological approach will be introduced, the findings from the content analysis presented and the results from the content analysis of texts from Aftenposten discussed. In the same ways that the media portray worthy and unworthy victims based on, inter alia, ethnicity, culture and religion, the argument of this article is that there also exists a gendered division, as the stories of female victims of sexual violence were reported extensively, whereas those of male victims were not, or at least not to the same extent. The preceding section is intended to show how media representations of sexual violence are gendered in themselves, and finally, to stress the importance of a gendered perspective when doing peace journalism.

\section{Sexualized Violence as a War Strategy}

During the war in Bosnia-Herzegovina, over 20,000 women were raped (Skjelsbæk, 2001:54). Historically, the raping of women has been accepted as a natural, inevitable consequence of war ${ }^{4}$. Feminists and human rights activists have fought for years to make women's experiences from war and conflict matter when building peace and doing postwar justice. Thus, when sexual abuse was recognized as a crime against humanity following the extensive, organized use of sexual violence in the war in the former Yugoslavia, part of a substantive - however overdue - battle was won. The mass media's exposure of the atrocities put pressure on the international society to recognize this. What is more, by creating public awareness about the rapes, the media made it possible for NGOs to raise money to start reconciliation projects and crisis centres for the women directly affected (Crowo, 1994). Further, the CEFR suggests that the media attention might have caused a real-time decline in the number of incidents of sexual violence (Bassiouni, 1994b) ${ }^{5}$. 


\section{The UN Commission of Experts' Final Report}

According to CEFR, the use of sexual violence aimed at men in detention camps was a widespread phenomenon in Bosnia. Yet to my knowledge, no estimates of the number of male victims of sexual violence exist, as they do for women. This paragraph provides some insight into the findings of the Commission.

During the years in which the Commission of Experts travelled around Bosnia ${ }^{6}$ to gather testimonies for the CEFR, they received information about a total of 715 camps. Out of these, 162 were continually reported to be sites in which detainees were sexually assaulted, the perpetrators being "guards, police, special forces, and others" (Bassiouni, 1994a). The report states that the Serbian side held almost 55\% of these sites, and that these were the camps in which the worst assaults were committed against the largest number of detainees. The Croatian camps - approximately $10 \%$ of all camps - were then again worse than those run by the Bosnian side, who 'only' comprised about $5 \%$ of the camps. Fourteen, or almost $9 \%$ of the camps in which sexual violence took place were run by Croats and Muslims together (Bassiouni, 1994a) ${ }^{7}$. The reports of sexual violence seem countless, and involve prisoners being forced to rape women, prisoners being forced to perform sex and same-sex acts on guards and each other, and prisoners being subjected to castration, circumcision and other sexual mutilation. The excerpts hereunder, none of which are exceptional compared to the rest of the report, are included to illustrate some of the assaults, and hence also to verify the aforementioned allegation about the 'if it bleeds...' proverb.

Men were subject to genital beatings and castration. [A] victim reported that he was repeatedly beaten in the genital area (...) and that a group of male prisoners, including himself, were lined up, their genitals were tied together with wire, and they were forced to walk around the room in which they were held (Bassiouni, 1994a).

Another ex-detainee told of suffering electric shocks to the scrotum and of seeing a father and son (...) forced by guards to perform sex acts with each other (Bassiouni, 1994b).

Male prisoners were forced to rape women and each other (...). In another incident, one man was forced to bite off the testicles of four men, reportedly after performing oral sex (...). In another incident, one man's testicles were tied with a wire. The other end of the wire was tied to a motorcycle. A guard drove the motorcycle off, castrating him (Bassiouni, 1994a).

The practice of castrating and assaulting men sexually during war and conflict is not new to history - it was "practiced by Chinese, Persian [and] Egyptian (...) armies" (Goldstein, 2001:357). The purposes might be manifold, but one repeated reason is that such practice serves the purpose of un-masculinizing, or feminizing, the enemy (Goldstein, 2001:357; see also von der Lippe, 2004:277). In a phallocentric culture, taking away the symbol of a man's manhood, i.e., his penis or his testicles, corresponds to taking away his power. Zarkov (2001:71-78), whose analysis deals with constructions of masculinity in Croatian and Serbian newspapers during the war, argues additionally that notions of masculinity and heterosexuality are inextricably linked to notions of ethnicity. Other commentators emphasize the "reciprocal relationship between militarism and masculinity" (Hopton 2003:113) and that "[m]ilitary masculinities are embed- 
ded into discourses of nationalism" (Higate 2003:209). Accordingly, forcing a man of another ethnic affiliation to perform same-sex acts or castrating him is "a proof not only that he is a lesser man, but also that his ethnicity is a lesser ethnicity" (Zarkov, 2001:78).

\section{Analytical Approach}

This analysis is based on a feminist, critical constructivist approach to international relations (IR) in general, and to war and peace journalism in particular. The combination of a feminist, critical constructivist approach sees patriarchy, the social context in which we live, as responsive to change. This makes the understanding of gender constructs, especially that of masculinity, essential for understanding and changing the political culture and hence also IR. In short, the critical constructivist approach emphasizes the possibilities we have to change the world. It understands the social world as one we construct and comprise as individuals through our intersubjective understanding of the social world, of its norms and its rules - hence, all social knowledge and social reality are socially constructed, and thus, amenable to change.

The feminist approach emphasizes the importance of a gendered perception of the world - of seeing gender everywhere - and recognizes the relation between - and within - the genders as power relations. Further, the approach is based on a belief that "the sources of discrimination against women [are embedded] in the economic, cultural, and social structures of society" (Tickner, 1992:15). These structures compose a larger patriarchal social reality, which is understood as a system that in various ways perpetuates the privileging of some men, associated with certain types of masculinities, over other men and women who fail to meet those 'standards' (Skjelsbæk, 1997a:23) ${ }^{8}$. Here 'masculinity' refers to the socially constructed gender identities of male human beings, i.e., it is built on a non-essentialist understanding of the term 'gender' ${ }^{9}$. In most societies, the hegemonic masculinity identities - that is, the dominating ideals of what is masculine - besides their being white and heterosexual, contain characteristics such as autonomy, strength, and to some extent aggressiveness. Finally and central to theory is the conception that 'the personal is political'.

It must be emphasized that this focus on men is not intended to challenge the focus on women victims or to shift the focus away from women victims, who in the world society at large, during peacetime as well as in war, comprise the largest demographic group of victims of sexual violence. Yet, based on the feminist approach advocated above, focusing on all the victims of sexual violence during the Bosnian war, including men, can provide valuable insights into the understanding of masculinities and patriarchy. As such, it does not oppose the framework presented, but rather enforces it. Also, the goal of feminism, as I see it, is to achieve de facto political, economic and social equality for all, regardless of race, ethnicity, culture, and gender $^{10}$ - not to replace a patriarchal society with a matriarchal one. Thus, taking male victims of sexual violence seriously is a righteous execution of the aphorism that what is personal - to women and to men - is also political. Further, the non-reporting of such violence is as detrimental to the 'feminist agenda' as it is to the stigmatized men who have been subject to the violence, as it sustains the very masculinized ideals and identities that continue to undermine women (and men) in patriarchal societies and 'lock' men into ideal hegemonic masculinity constructs. 


\section{Feminist Constructivism and Peace Journalism}

Peace journalism (PJ) is in many ways to journalism what feminist constructivism is to IR theory. Just as constructivism does, PJ advocates a people-centred focus, emphasizing complexity and process, and is solution-orientated. Just as feminist constructivism is considered a 'softer' form of theory, a minor niche stand of IR - so is PJ cut off from the mainstream, and not implemented in typical reporting (Lynch \& McGoldrick, 2004:195). Just as feminist constructivism is pushed aside by realpolitik - which sees the world in a more static and dichotomous way with winning and losing states, with fear and deterrence politics - PJ is also pushed aside by war journalism - which is war, violence and victory oriented (Galtung, 2002:261). Consequently, starting from a feminist constructivist perspective on IR, it is not hard to choose PJ to be the journalistic outlook for the media analysis in question.

One of the main focuses of PJ is that it has to be people-oriented. This involves, quoting Galtung (2002:261), a "focus on suffering all over; on women, aged, children, giving voice to the voiceless". In contrast, war/violence journalism is elite-oriented and thus focuses "on 'our' suffering; on able-bodied elite males" (Galtung, 2002:261; Lynch \& McGoldrick, 2005:6). Thus, “[p]eace journalism is a 'journalism of attachment' to all actual and potential victims" (Galtung, 2000:262), and hence, reporting on sexual violence committed in detention camps during the war in Bosnia-Herzegovina should also include male victims. But, when Galtung (2000:263, 267-268) acknowledges the importance of gender in his presentation of PJ, it appears that by 'gender' he actually means 'women', and by the differentiation between male/female he seems to be referring to biological sexes, not socially constructed genders amenable to change. For PJ to undertake a conscientious understanding and adaptation of gender perspectives in analysis and reporting, it has to define gender as comprised of various constructs of femininity and masculinity, which affect and construct both women and men. Having a gender perspective involves more than just reporting the suffering of 'women, children and elderly' men possess gender too. In other words, "[s]tereotypical essentializing of women as 'victims' and men as 'perpetrators' of political violence and armed conflict assumes universal, simplified definitions of such phenomena" (Moser \& Clark, 2001:4). When writing about PJ, and more important, when doing it, this should be emphasized to avoid the essentialist fallacy of gender. Accordingly, this article can also be read as a wellintended criticism of peace journalism's (poor) gender perspectives.

\section{Methodological Choice}

The research question is addressed through the use of content analysis of relevant newspaper texts from a period of 13 years, from January $1^{\text {st }} 1992$ until December $31^{\text {st }} 2005$, with a heavy focus on relatively straightforward quantitative measures. According to Weber (1990:9), “[c]ontent analysis is a research method that uses a set of procedures to make valid inferences from text. These inferences are about the sender(s) of the message, the message itself, or the audience of the message" - the discussion in this article will involve, to a varying extent, inferences about all these aspects.

The Norwegian newspaper Aftenposten was chosen for the analysis based on consideration of several aspects. First and foremost, a written media was chosen for the sake of convenience; a comparable analysis of TV news or radio broadcasts would be too time-consuming, considering the time-span of the analysis. Second, Aftenposten was favoured above English and/or international newspapers on account of availability. 
Atekst ${ }^{11}$, the web-based archive from which the textual units for the analysis were gathered, consists of Norwegian newspapers, and is easily available to students enrolled at Norwegian Universities. Third, due to limits of space, the analysis is restricted to only one newspaper, and Aftenposten was favoured because it is the largest national non-tabloid newspaper in Norway.

Atekst allows specification of universe, time-span and search variables. To ensure that all articles relevant to the analysis were included in the search, several "pilot searches' were performed using different defining variables. In this way, the variables finally used for analysis are believed to include all texts reporting on the war in Bosnia that specifically involve some sort of sexual violence ${ }^{12}$. To ensure accuracy, sexual violence is defined according to the definition provided in the Final Report as rape or any other "forced or coerced sexual acts [and] sexual mutilations" (Bassiouni, 1994a).

The search variables turned out to possess some ambiguity in terms of meaning, and were not specific enough to exclude all excess texts that were irrelevant to the analysis. This made more in-depth reading of the articles necessary to define which were relevant, in this way compensating for the insufficient variable validity. This makes replication of the analysis more laborious, yet these criteria were kept, out of concern that some relevant articles might otherwise be excluded. When the articles relevant for analysis were set, their content was divided into mutually exclusive categories of gender and ethnicity specified for both victim(s) and perpetrator(s), and then the type of sexual assaults were counted. The results are presented in the next section.

The analysis is complemented by information obtained through short e-mail interviews with journalists who wrote some of the analysed texts. The selection of journalists was made based on the relevance of their articles' content.

\section{Gendered Victims or Gendered Women?}

The immediate search result in Atekst was 421 texts. A qualitative content check ${ }^{13}$ of these texts results in a final number of 193 texts. Articles that implicitly bring up sexual assaults using terms such as 'atrocities', 'war crimes' etc. are not among the final 193 unless they also contain one or more of the defined search variables (see endnote 12).

The 193 texts were divided into two categories: one in which the subject of sexual assaults is essential to the content, which was the case for about $30 \%$ of the text units; and the other category, the 'mention only' category, consists of texts in which the sexual assaults are simply mentioned without the topic being critical to the content or further developed. The latter category includes the remaining $70 \%$ of texts.

Furthermore, the texts were examined with respect to gender and ethnicity presentations of both victims and perpetrators of sexual violence. The ethnicity variable is included to see whether the analysis showed any difference in the gender presentation in relation to ethnicity of victim and/or perpetrator. The analysis encompasses presentations of perpetrators to see whether these are more or less gendered than are victims. This will help in making inferences about masculinity constructs in the media in the discussion part of this article.

The results reveal that in the vast majority of texts, the victims of sexual violence are women, or the gender is not defined (see bottom horizontal line, Table 1 below). Gender is defined in $54.9 \%$ of the texts. Eighty-five of the 87 texts in which gender is not defined belong to the 'mention only' category above. The residual two texts that do not define gender and that have sexual violence as a main subject are, respectively, a debate 
contribution from a reader and an article dealing with forced nudity, and as such, not 'typical' sexual violence. In only four text units are the victims of sexual violence exclusively men, out of which one text is a note, and the remaining three texts are under the 'mention only' category. In contrast, 90 texts mention women exclusively. Sometimes sexual violence is listed as one of several assaults or means of torture to which 'men and women' were exposed, without specifying which assaults were perpetrated against women and which were perpetrated against men. These texts comprise the 'Both' category, together with the texts in which the crimes are specified for both genders.

The quantitative analysis of the ethnicity variable in Table 1 (column furthest to the right) shows that in about $50 \%$ of the texts, the victims of sexual assaults are Bosnian, Bosnian/Muslim or Muslim, out of which $60 \%$ are Bosnian women. Bosnian women comprise $63.3 \%$ of all texts exclusively reporting female victims, who again comprise $46.6 \%$ of all victims. Thirty percent of the analysed texts do not define the ethnicity of victims of sexual assaults. Out of the four text units that exclusively mention male victims of sexual assaults, two refer to Bosniaks, whereas the remaining two are not defined and under the 'Other' category, respectively. None of the victims are reported to be Croatian.

Table 1.

\begin{tabular}{|c|c|c|c|c|c|c|c|c|c|c|c|c|c|c|}
\hline \multirow[b]{2}{*}{ Ethnicity } & \multicolumn{3}{|c|}{ Female } & \multicolumn{3}{|c|}{ Male } & \multicolumn{3}{|c|}{ Gender } & \multicolumn{3}{|c|}{ Not defined } & \multicolumn{2}{|c|}{ Ethnicity } \\
\hline & $\mathrm{N}$ & $\mathrm{P}_{\mathrm{f}}$ & $\mathrm{P}_{\mathrm{EB}}$ & $\mathrm{N}$ & $\mathrm{P}_{\mathrm{m}}$ & $\mathrm{P}_{\mathrm{EB}}$ & $\mathrm{N}$ & $\mathrm{P}_{\mathrm{b}}$ & $P_{E B}$ & $\mathrm{~N}$ & $\mathrm{P}_{\mathrm{ND}}$ & $P_{E B}$ & & $\mathrm{P}_{\text {Tot }}$ \\
\hline Bosnian & 57 & 63.3 & 60.0 & 2 & 50.0 & 2.1 & 5 & 41.7 & 5.3 & 32 & 36.8 & 33.7 & 96 & (49.7) \\
\hline Croatian & - & - & - & - & - & - & - & - & - & - & - & - & - & - \\
\hline Serbian & 2 & 2.2 & 50.0 & - & - & - & 1 & 8.3 & 25.0 & 1 & 1.1 & 25.0 & 4 & (2.1) \\
\hline Non-Serbian & 1 & 1.1 & 25.0 & - & - & - & - & - & - & 3 & 3.4 & 75.0 & 4 & (2.1) \\
\hline Any Combination & 10 & 11.1 & 66.7 & - & - & - & 2 & 16.7 & 13.3 & 3 & 3.4 & 20.0 & 15 & (7.8) \\
\hline All Parties & 6 & 6.7 & 40.0 & - & - & - & 4 & 33.3 & 26.7 & 5 & 5.7 & 33.3 & 15 & $(7.8)$ \\
\hline Not Defined & 14 & 15.6 & 24.1 & 1 & 25.5 & 1.7 & - & - & - & 43 & 49.4 & 74.1 & 58 & (30.1) \\
\hline Other ${ }^{14}$ & - & - & - & 1 & 25.5 & 100 & - & - & - & - & - & - & 1 & $(0.5)$ \\
\hline Gender, $\mathrm{N}_{\text {Tot }}$ & 90( & $(46.6)$ & & 4 & (2.1) & & 12 & (6.2) & & $87(4$ & 45.1) & & 193( & $(\sim 100)$ \\
\hline
\end{tabular}

Note: Specification of victims' gender and ethnicity in all text units. Explanation of entries: 'Bosnian' refers to any of the three references 'Bosnian', 'Bosnian Muslim' and/or 'Muslim'; 'Serbian' refers to 'Serbs' or 'Bosnian Serbs'; 'Any Combination' refers to any text in which two different ethnicities are presented in combination as victims; and 'All Parties' equals 'Serb', 'Croats' and 'Bosniaks'. 'N' equals absolute numbers, whereas numbers under ' $P_{X}$ ' are percentages. ' $P_{f}$ ' is, thus, the percentage female victims of a given ethnicity comprise out of all texts mentioning female victims. The total of female victims can be read from the bottom horizontal line, with the percentage these comprise out of all victims in all texts in parenthesis. The same applies to all categories of gender. Numbers under ' $P_{E B}$ ' give the percentage the given gender comprises of all victims of the given ethnicity. In the right hand column, the total of victims belonging to a given ethnicity can be read, with the percentage these comprise out of all victims in all texts in parenthesis ${ }^{15}$.

As for the perpetrators, none of them are explicitly said to be women, and most of them, $71.1 \%$, are not defined to any gender (see bottom horizontal line, Table 2 below). Out of the five texts in the 'Both' category, one refers to an incident in which demonstrating Serbian women denied UN forces access to a mental hospital abandoned by the employees. Several patients in the hospital were wandering around naked in the cold, and needed care. The sexual assault was indirect and not caused by these women, but is nevertheless included (NTB et al., 1993). Another text states that women were also perpetrators (Andenæs, 1994), and the latter three refer to women who became pregnant 
after rape and subsequently abandoned their newborns, hated them and/or killed them. Although these actions are not sexual in any way, they are the direct results of sexual violence and therefore included. These women are also defined as victims of sexual violence in Table 1.

The quantitative analysis of the ethnic variable for perpetrators of sexual violence in Table 2 (column furthest to the right) shows that $46.1 \%$ of the texts define the perpetrators as Serbian or Bosnian Serbs, out of which $46 \%$ are male Serbs. Texts referring to male Serbian perpetrators comprise over $80 \%$ of all references made to male perpetrators. About $35 \%$ of the texts do not define the ethnicity of the perpetrators and one explicitly identifies the perpetrators as Bosnian. Of the 14 texts (7.3\%) stating that all parties were involved in sexual atrocities, 11 emphasize that the worst atrocities were committed by the Serbian side, and that the Serbian warring fractions were responsible for the largest number of such atrocities.

\section{Table 2.}

\begin{tabular}{|c|c|c|c|c|c|c|c|c|c|c|c|c|c|c|}
\hline \multirow[b]{2}{*}{ Ethnicity } & \multicolumn{3}{|c|}{ Female } & \multicolumn{3}{|c|}{ Male } & \multicolumn{3}{|c|}{$\begin{array}{c}\text { Gender } \\
\text { Both }\end{array}$} & \multicolumn{3}{|c|}{ Not defined } & \multicolumn{2}{|c|}{ Ethnicity } \\
\hline & $\mathrm{N}$ & $\mathrm{P}_{f}$ & $P_{E B}$ & $\mathrm{~N}$ & $\mathrm{P}_{\mathrm{m}}$ & $P_{E B}$ & $\mathrm{~N}$ & $\mathrm{P}_{\mathrm{b}}$ & $P_{E B}$ & $\mathrm{~N}$ & $\mathrm{P}_{\mathrm{ND}}$ & $\mathrm{P}_{E B}$ & $\mathrm{~N}_{\text {Tot }}$ & $\mathrm{P}_{\text {Tot }}$ \\
\hline Bosnian & - & - & - & 1 & 2.0 & 100 & - & - & - & - & - & - & 1 & 0.5 \\
\hline Croatian & - & - & - & 2 & 3.9 & 50.0 & - & - & - & 2 & 1.5 & 50.0 & 4 & 2.1 \\
\hline Serbian & - & - & - & 41 & 80.4 & 46.0 & 1 & 20.0 & 1.1 & 47 & 34.3 & 52.8 & 89 & 46.1 \\
\hline Any Combination & - & - & - & 4 & 7.8 & 26.7 & 3 & 60.0 & 20.0 & 8 & 5.8 & 53.3 & 15 & 7.8 \\
\hline All Parties & - & - & - & - & - & - & 1 & 20.0 & 7.1 & 13 & 9.5 & 92.9 & 14 & 7.3 \\
\hline Not Defined & - & - & - & 1 & 2.0 & 1.5 & - & - & - & 66 & 48.2 & 98.5 & 67 & 34.7 \\
\hline Other ${ }^{16}$ & - & - & - & 2 & 3.9 & 66.7 & - & - & - & 1 & 0.7 & 33.3 & 3 & 1.6 \\
\hline Gender, $\mathrm{N}_{\text {Tot }} \mathrm{P}_{\text {Tot }}$ & & - & & 51( & (26.4) & & 5 & (2.6) & & 137( & 71.0) & & 193( & -100) \\
\hline
\end{tabular}

Note: Specification of perpetrators' gender and ethnicity in all text units. Table 2 is to be read as Table 1 , only change 'Victim' for 'Perpetrator'.

In sum, gender is more visible for victims than it is for perpetrators - the 'Not Defined' category constitutes $45.1 \%$ and $71 \%$, respectively - and as expected, women victims are by far more exposed than are male victims. Further, the ethnicity variable is to a slightly higher extent defined for victims than for perpetrators (the 'Not Defined' category constitutes $30.1 \%$ and $34.7 \%$, respectively). Notwithstanding, the most prevalent group of victims presented corresponds relatively well with the most frequently reported ethnicity of perpetrators; $49.7 \%$ of the victims are identified as Bosnian, Bosnian/Muslim or Muslim, whereas $46.1 \%$ of the perpetrators are defined as Serbian or Bosnian/Serbs in the analysed texts from Aftenposten.

Finally, the kinds of sexual assault Aftenposten reported during the defined time period were counted and the results are listed in Table 3 below. The table also includes a gender specification of victims of the sexual assaults defined. Several assaults are sometimes mentioned in the same text, and if they are gender specific but different assaults, and victims of both genders are mentioned, Table 1 above presents the victims' genders under the category 'Both'. Here, this is largely avoided because the assault itself is specified. Thus, the numbers presented here do not correspond completely to those in Table 1, as a total of 214 references to sexual violence were made in the 193 conferred texts.

Table 3 reveals that 183 out of the 214 reports (85.5\%) deal with rape as sexual violence, and that 83 out of the 89 text units for which the victims' gender is not defined 
concern rape. In addition, this table reduces the 'Both' category in Table 1 from 12 text units to six reports. One of the six assaults that are removed from the 'Both' category deals with male victims, whereas the other five were moved to the 'Female victim' category. Out of the six cases that still involve victims of both genders, three do not specifically state that men were subject to the sexual violence, but list sexual violence as one of several assaults to which 'men and women' were exposed. Out of 214 reports of sexual violence, in 193 text units, nine (4.2\%) are specifically reports about men who have been subjected to sexual assault. One involves a man who refused to rape a woman, one involves only external military personnel, one mentions forced nudity and six report sexual mutilation.

Compared to Table 1, where each individual text unit determines the gender presentation and not each specific report of sexual assault, there is a moderate shift towards a higher gender specification for victims, evident in the change in percentages under 'Not Defined' - from $45.1 \%$ to $41.6 \%$. Also, the percentage share of male victims of sexual assault was doubled, from $2.1 \%$ to $4.2 \%$, which still is a low number (nine reports). Overall, the relative shares of the different genders are not substantially changed when the assaults are specified compared to Table 1's presentation of text units.

Table 3.

\begin{tabular}{|c|c|c|c|c|c|}
\hline Type of Assault & $\mathrm{N}$ & Victim (F) & Victim (M) & Both & Gender (ND) \\
\hline Forced Prostitution & 2 & 2 & & & \\
\hline $\begin{array}{l}\text { Forced Rape and } \\
\text { subsequent killing }\end{array}$ & 2 & & 1 & 1 & \\
\hline Mass Rape & 29 & 14 & & & 15 \\
\hline Rape & 120 & 51 & 1 & $2^{17}$ & 66 \\
\hline Rape Camps & 1 & 1 & & & \\
\hline Rape as WOW ${ }^{18}$ & 14 & 12 & & $1^{19}$ & 1 \\
\hline Revenge Rapes & 2 & 2 & & & \\
\hline Systematic Rape & 13 & 12 & & & 1 \\
\hline Castration & 2 & & 2 & & \\
\hline Circumcision & 1 & & & & 1 \\
\hline Forced Nudity & 4 & 2 & 1 & & 1 \\
\hline Forced Pregnancy & 11 & 11 & & & \\
\hline Mutilation & 1 & 1 & & & \\
\hline $\begin{array}{l}\text { Prisoners forced to bite } \\
\text { off the testicles of other } \\
\text { prisoners }\end{array}$ & 2 & & 2 & & \\
\hline $\begin{array}{l}\text { Prisoners forced to } \\
\text { castrate each other }\end{array}$ & 2 & & 2 & & \\
\hline Sexual Assault & 6 & & & 2 & 4 \\
\hline Sterilization & 1 & 1 & & & \\
\hline Witness to Rape & 1 & 1 & & & \\
\hline $\mathrm{N}_{\text {Total }}$ & $214(100)$ & $110(51.4)$ & $9(4.2)$ & $6(2.8)$ & $89(41.6)$ \\
\hline
\end{tabular}

Note: The 214 sexual assaults to which the 193 text units refer, with sub-categories of the victims' gen$\operatorname{der}($ Female $=$ 'Victim $(\mathrm{F})$ '; Male = 'Victim $(\mathrm{M})$ '; Both = 'Both'; and incidents for which no gender are identified $=$ 'Gender (ND)'). The bottom horizontal line presents the cumulative actual (absolute numbers) and relative (percentages) representations of gender for all sexual assaults. Numbers in parenthesis in the bottom horizontal line give the percentage the specific gender of victim comprises of all reports on sexual violence. 
The two articles in the category 'Forced rape and subsequent killing' in Table 3 report two specific events related to the practice of forcing prisoners to rape each other. The first article briefly mentions that a Bosnian man was killed in detention at the Omarska camp because he refused to rape a young woman (Haabeth, 1993:2). The other, which is an article about the conditions at Omarska, reports on a Muslim man who was forced to undress together with a young girl and then told to rape her, which he refused to do. Consequently the guards beat him and then told him to rape her with his fingers. The man did so, and was then killed (Nordstrøm, 1996:7). The first article is included even though no actual rape took place, because the killing was a direct result of the practice of rape and forced rape.

\section{Lack of Information}

Three journalists responded and reflected on my request concerning the issue of sexual violence towards men during the war in Bosnia. None of them knew about the sexual assaults directed against men at the time they were reporting and two said they could not remember if they had read the Final Report. One said that if she had heard of extensive sexual abuses of men, she would not have hesitated to further investigate them, or to write about them, nor would the newspaper in general (Nordstrøm, 2006, pers. comm.). The other interviewee limited her role in the coverage of Bosnia, as she was working in another office at the time. Because of her position, she did not participate in the current discussions about Aftenposten's coverage and priorities on the subject, thus she spoke on behalf of herself, not the paper (Harbo, 2006, pers. comm.). She emphasized that she did not know, at the time of her reportage trip, about the extent to which sexual violence was committed against men, and further that there was little focus on this phenomena in general. Of the three respondents, she was the only one whose articles on sexual assault had been published prior to the release of the Final Report. She still reflected on the issue of a potential taboo in the media related to sexual violence against men, but rather suggested that there probably is a greater stigma attached to being a male victim than a female, which makes reporting on such violations more difficult for journalists.

The last journalist who responded had not read the Final Report and he could not remember it being mentioned in any other media. The interviewee concluded that Aftenposten had not made a conscious decision not to focus on sexual violence against male victims, and asserted that there are no constraints whatsoever that make male victims to sexual assaults less 'attractive' to media institutions than female victims (Willersrud, 2006, pers. comm.).

\section{Negotiating Gender}

\section{Evaluation of Findings}

This analysis started from a few underlying assumptions: i) that the media, as represented by Aftenposten, gave a poor presentation of male victims of sexual assault in coverage of the war in Bosnia; and ii) that the poor presentation had to do with, inter alia, masculinity constructs and a lack of gender sensitivity. The CEFR provides valuable information about the practice of sexual violence towards both women and men. Anyone who questions the assertion made here about the extensive and institutionalized abuse of men can take a thorough look in this report ${ }^{20}$. However, as no estimates exist 
on the number of men who were subjected to sexual violence during this war, it is hard to approximate what would be a fair presentation of these victims in news coverage. Nevertheless, I still hold that the actual presentation evident in Aftenposten, based on this analysis, was poor. For instance, not a single article dealt in-depth with male victims of sexual assault. The longest report on the issue was about the man who was forced to finger-rape the young girl; this only amounted to seven lines (in Atekst format).

As mentioned, the analysis encompassed presentations of perpetrators to see whether these were more or less gendered, i.e., presented as holders of sex, than were the victims. The results are clear: In Aftenposten victims were more gendered than were perpetrators. Whereas $71 \%$ of the presentations of perpetrators were neither specified as male nor female, and about a quarter of them identified the perpetrators as men, only $45.1 \%$ of the victims were not gendered, and $46.6 \%$ of the victims were identified as women $(41.6 \%$ and $51.4 \%$, respectively, if using Table 3$)$. According to the presented framework this finding can be interpreted as asymmetrical gender sensitivity, sustaining the acceptance of dominant masculinity constructs that undermine women and men who fail to meet that standard.

It could be argued that the 89 reports of sexual violence for which no gender is specified, or the 87 texts in which no gender is mentioned, also include male victims, precisely because of their gender neutrality. Even so, there are some linguistic connotations to be addressed that can substantiate the counter-argument that these 87 texts $(45.1 \%)$ did not leave readers with the impression that they also concerned men. To illustrate, some of the analysed texts listed several assaults that men and women were subjected to, among which one was 'rape' or 'rape as a weapon of war'. For instance, one report about the prosecution of a war criminal in ICTY states: "Dusan Tadic (41) is charged with murder, torture and rape of Muslim (...) women and men" (Mathismoen, 1996, my translation). The immediate perception of this statement is likely to be that Tadic raped (and murdered) women and murdered and tortured men. Correspondingly, when reports of rape and mass rape do not report the gender of victims, it is likely that the reader unconsciously perceives the victims of the sexual violence to be women.

Thus, from a critical constructivist and feminist perspective, it can be argued that the (female) gendering of victims and the overall non-gendering, or non-reporting, of male victims reinforce the traditional gender roles feminists try to escape - roles in which women are innocent, inherently peaceful, passive victims, and men are the opposite: independent and inherently aggressive actors, and thus left out of the role of victims of sexual assault. Aftenposten demonstrates its failure to report 'suffering all over' in its neglect of male victims, a central prerequisite of PJ.

The lesser extent to which perpetrators are presented as gendered would seem to contain at least two aspects. First, 'man' often represents the norm, i.e., the natural gender, when it comes to positions of power. Accordingly, "he can appear to be asexual or gender neutral in language usage" (Eide \& von der Lippe, 2003:266, my translation). For instance, we rarely read or hear about 'male lawyers', 'male Supreme Court advocates' or 'male Secretaries of State', as these would be considered pleonasms. On the contrary, presentations of a 'female lawyer' or a 'female Supreme Court advocate' would hardly make anyone wonder about the terminology. Correspondingly, it is no surprise that presentations of perpetrators of sexual violence are ungendered more often than not, because they are expected to be male. In contrast to this, 'female victims of rape' is not as apparent a pleonasm, when comparing the gendering of victims to that of perpetrators $($ Table $3+4)$. Again, this supports the traditional 'women as victims' gender role, 
and is therefore not unexpected from the perspective of a theoretical framework that sees most societies as patriarchal structures with self-interests in keeping this tradition.

Second, when the media present a perpetrator of sexual violence as gender-neutral, this obscures an action that is gendered per se. After all, it is as possessors of gender that perpetrators commit these violations and victims are exposed to them. Hence, in accordance with the feminist approach emphasized here, both perpetrators and victims should always be identified with their gender. Such a simple terminological move could serve the purpose of reminding both the writer and the reader of gendered power relations (Eide \& von der Lippe, 2003:277). Further, it would ensure that both female and male victims (as well as perpetrators) become visible in media, and none neglected due to ignorance of their gender.

The ethnicity variable was included to see whether the analysis showed any difference in the gender presentation in relation to ethnicity of victim and/or perpetrator. As mentioned, the CEFR estimated that the Serbian side held over half of the camps in which it was reported that the largest number and worst kind of sexual atrocities took place. Table 2 shows that $46.1 \%$ of the analysed texts present the perpetrators as Serbian or Bosnian Serbs. As for Bosnian-run and Croat-run camps, they comprised respectively $5 \%$ and $10 \%$ of the total of 162 camps. In Table 2 , only $0.5 \%$ of the texts identify perpetrators as Bosnian and only $2.1 \%$ are identified as Croats. Because no numbers of actual, individual perpetrations of women and men are given in the report or in the texts from Aftenposten, no further comment will be made on this finding.

In relation to both perpetrators and victims, definitions in ethnical terms are used to a higher extent than is the gender variable. In $63.8 \%$ of the text units, the perpetrators are associated with their ethnicity, and the corresponding number for victims is $69.5 \%$. As stated, only $29 \%$ of the perpetrators are gendered, compared to $54.9 \%$ of the victims. Hence, in sum, ethnicity - a socially constructed identity - is valued more in describing victims and perpetrators of sexual violence than is their gender. In light of the overall presentations of this particular war in the media as a whole - i.e., as a nationalistic and ethnic war - the emphasis on ethnicity is nothing more than expected. Yet, if one accepts that it is as carriers of gender that perpetrators rape or otherwise sexually assault, is it not conspicuous that their gender is not deemed at least equally important?

\section{Possible Explanations}

Given that the coverage of male victims of sexual violence is poor, what might be the reasons for this? According to the three journalists who covered the sexual violence, there is no explanation they can give for the lack of coverage other than the fact that they did not know about the extensive abuses of men. There is no reason to question them on their comments, and it is possible that their comments are generalizable to all journalists covering the war. Obviously, a reporter cannot write about something she or he has never heard of. Notwithstanding, considering that the CEFR was publicly available from May 1994, not knowing about the sexual violence against men in the succeeding years of coverage may serve as an explanation for the actual, deficient coverage, but not as a justification for it. Yet, if that report, and a few articles, were (and still are) the only sources of evidence that extensive assaults of men took place, one needs to consider the reasons for this, as the literature base on sexual violence against women is extensive.

Following Kempf and Luostarinen (2002:8), the issues that get reported in the news are generally those with "easy access, journalistically interesting material, dramatic 
David-and-Goliath constellations and public relations effort". Two of these four demands are not fulfilled when it comes to sexual violence against men; the access issue has already been addressed, and second, to some extent, the "David-and-Goliath constellations" are not prevalent, as it is mostly men raping or performing sexual acts on other men. Further, as "journalists suppressed news stories that satisfied all criteria for newsworthiness but did not fit the image of the enemy" (Kempf, 2002:60) during the wars in the former Yugoslavia, one might wonder whether they, or some of them, have also unconsciously suppressed stories that do not fit the image of masculinity.

Another and less controversial reason for the insignificant reporting of male victims of sexual violence is the social stigma attached to rape and other forms of sexual abuse. Potentially, and probably, there is an even greater social stigma attached to men than to women, as men risk the association to homosexuality. Indeed, one commentator stresses that "[s]hame is the glue that holds the man-making process together. Males who fail tests of manhood are publicly shamed, humiliated, and become a negative example for others (...). The power of shame should not be underestimated" (Goldstein, 2001:269). As mentioned previously, homosexuality does not correspond to the dominant masculinity construct standard of what is deemed 'a real man' and what it is to be 'masculine'. In addition, men probably choose not to come forward, as there generally are few who share the same experience (Skjelsbæk, 1997b). Thus the 'gatekeepers' who decide whether or not these forms of violence reach the news are not exclusively or necessarily the journalists or the editors, but the victims themselves - an acknowledgement that makes the very reporting in the media even more valuable. Not only can the media be "regarded as social tools to construct gender" (Eide \& von der Lippe, 2003: 278, my translation) in the ways they emphasize and present news and individuals. Also, media "give signals not only about what is important, but about who is important, who matter in society" (Eide \& von der Lippe, 2003: 279, my translation). Thus, if the media also take male victims of sexual violence seriously, and report about them, the social stigma will probably be relieved, at least to some extent, by making these individuals visible and worthy of reporting.

\section{Concluding Remarks}

At the core of this paper was a postulation about the importance of a fair understanding and adaptation of gender perspectives in the journalistic process. Hopefully, this article can function as a helpful reminder that we need to 'see gender everywhere'. The implementation of such perspectives in relation to male victims of sexual assaults can potentially impact both the micro and macro level of society. As for the micro level, reporting on both male and female victims of sexual violence is likely to reduce the social stigma most victims experience. Atrocities such as these should never be allowed to go on in silence and unchallenged, no matter the numbers of victims to them. Further, if the media address the issue of sexual violence against men, they will not only give a voice to those affected by such violence, but also challenge, instead of perpetuate, discriminating masculinity constructs at the macro level.

This analysis acknowledges that, for a journalist, "[t]o 'report the facts', in the timehonored phrase, is to suppress - inescapably" (Lynch \& McGoldrick, 2005: xvii). Every single atrocity committed in war simply cannot make it to the media outlets, even less to a single newspaper. Thus, every media outlet has to select and omit, and this selection process inevitably silences the stories of those countries, groups and individuals that 
are not reported on. Is it reasonable to expect of journalists and editors that they, in the selection process, take into consideration feminist perspectives, and also report stories that involve subversive constructs of masculinity? I argue that, for journalists aiming to do PJ, this is not a preposterous assumption. Both on a general basis, and in particular in relation to the coverage of sexual violence, it will ensure that no victims are silenced merely because of their gender. It being difficult at times is no excuse for not doing it.

\section{Notes}

1. In the former Yugoslavia, kinship is patrilinear, that is, the ethnicity of a child follows that of the father. Thus, raping women was a way to increase one's own ethnic population through forced pregnancies.

2. See, inter alia, Stiglmayer (1994) and Moser \& Clark (2001).

3. CEFR was established pursuant to Security Council Resolution 780 (1992), and was completed the 27th of May 1994. The mandate was to provide "conclusions on the evidence of grave breaches of the Geneva Conventions and other violations of international humanitarian law committed in the territory of the former Yugoslavia" (Bassiouni, 1994d).

4. Ruth Seifert (2001:58) argues that there are three explanations for widespread use of rape in war: i) a historical acceptance of the winning party's right to the counterpart's women; ii) rape as message to the counterpart that he and the men around him are unable to protect 'their' women; and iii) gang rape - which is common particularly in war - creates solidarity and enforces the 'brotherhood of men'.

5. When references are made to different sections of the CEFR, they will take the form of 'Bassiouni, 1994...'. Mr. Bassiouni was the head director of the Commission.

6. The Commission started its work in November 1992 and concluded its work in April 1994.

7. 35 of the 162 camps, about $20 \%$, were run by unknown forces.

8. Here, the notion of patriarchy is not meant as the domination of all men over all women. Rather it is the domination of some (male) actors over other (male and female) actors who to a greater or lesser extent are passivized.

9. Gender is understood as constructed in interaction (sociology of gender), not determined by or inherent in the individual's biological sex. Who you are is defined by the kind of person you are socialized into being, which depends on each individual's lived experience and, inter alia, on the contemporary, contextual constructs of femininity and masculinity. Those constructs represent what having a specific gender means at the time, and are - and this must be emphasized - dynamic, i.e., culturally, socially and historically specific (Connell, 2000:25).

10. - or any other socially constructed divides of human beings -

11. Web-address: http://www.retriever-info.com/services/archive.html

12. The criteria defining the units of analysis.

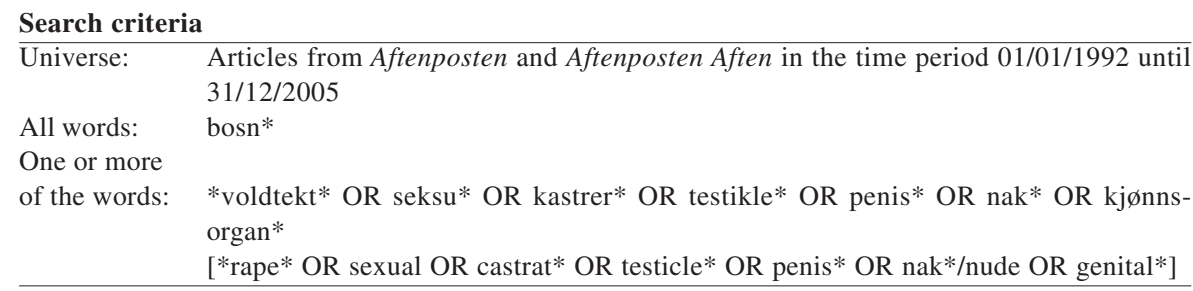

Asterisk: the ending/beginning of the word is not defined - ensures that verbs, adjectives, singular and plural forms of every core word are included.

13. Qualitative content analysis here refers to the process of excluding articles for which the search criteria were fulfilled but in which the variables referred to other events than those in question. An example is the use of metaphors: 'the naked city of Sarajevo' or 'the rape of Bosnia'.

\section{Acknowledgement}

I would like to thank Professor Rune Ottosen at Oslo University College for his constructive, encouraging comments. Also, I enjoyed the invaluable help and support of Andreas Hessen Schei and Marianne Johannessen. 
14. The one unit that falls under the 'Other' category refers to an incident in which a Dutch NATO corporal accused two British soldiers of raping him while on duty in Bosnia (NTB/DPA, 2001).

15. To illustrate: If starting at first entry in the left hand column, 'Bosnian', what can be read from left to right, is: 57 text units mention exclusively Bosnian female victims to sexual violence. Bosnian female victims comprise $63.3 \%$ of all references to female victims in Aftenposten, and the 57 text units comprise $60 \%$ of all text units that mention Bosnian victims irrespective of their gender. The corresponding numbers for male Bosnian victims can be read from the next three columns, then for both genders and finally for victims for which no gender was mentioned.

16. The 'Other' category here refers to an incident in which British soldiers allegedly raped a fellow UN soldier from the Netherlands; a case where UN soldiers of different nationalities while on duty in Bosnia were suspected for visiting a brothel where women were forced into prostitution; and an article in which Islamic extremists were believed to be involved in grave violations during the war in Bosnia.

17. These two articles do not specifically state that both men and women were raped, but rape is listed as one of several assaults which 'men and women' were exposed to.

18. WOW= Weapon of War. Refers to rape as a strategy to achieve military goals. Three of these specifically stated that rape was part of a strategy to perform 'ethnic cleansing'. All three stated women as victims.

19. See footnote 17 .

20. Of particular relevance are Annex IX: Rape and Sexual Assault and Annex VIII: Prison Camps (Bassiouni, 1994a; 1994c).

21. For a future study, it would be interesting to see how well theories of gender constructs and the reporting of male victims of sexual abuse resonate with the theory of worthy and unworthy victims in the news coverage. Such an analysis should also include the recent media coverage of abuses in Abu Ghraib, Iraq.

\section{References}

Andenæs, U. (1994) 'Vannviddet rammet også Maluhia. Spillet om Sarajevo' [Insanity hit Maluhia too. The Game over Sarajevo], Aftenposten, 19/02/1994.

Bassiouni, M. (1994) Final Report of the United Nations Commission of Experts established pursuant to Security Council Resolution 780 (1992). S/1994/674/Add.2 (Vol. 1) 28/12/1994.

Bassiouni, M. (1994a) 'Annex IX. Rape and Sexual Assault' in Bassiouni, 1994. Available at http:// www.ess.uwe.ac.uk/comexpert/ANX/IX.htm

Bassiouni, M. (1994b) 'Section IVF Rapes and Other forms of Sexual Assaults' in Bassiouni, 1994. Available at http://www.his.com/ twarrick/commxyu5.htm\#IV

Bassiouni, M. (1994c) 'Annex VIII Prison Camps - Part 1/10' in Bassiouni, 1994. Available at http:// www.ess.uwe.ac.uk/comexpert/ANX/VIII-01.htm

Bassiouni, M. (1994d) 'Section IVE Detention Facilities' in Bassiouni, 1994. Available at http:// www.his.com/ twarrick/commxyu5.htm\#IV

Connell, R. (2000) 'Arms and the man: using new research on masculinity to understand violence and promote peace in the contemporary world' in Breines, I., Connell, R. \& Eide, I. (eds.) Male Roles, Masculinities and Violence. A Culture of Peace Perspective. UNESCO Publishing: Paris (21-33).

Crowo, J. (1994) 'Uten massemedia mindre penger' [Less money without mass media] Aftenposten. 04/08/ 1994.

Eide, E. \& von der Lippe, B. (2003) '̊̊ lese medier i kjønnsbriller' [Reading Media Through Gendered Lenses] in von der Lippe, B. (ed.) Medier, Politikk og Samfunn. Oslo: Cappelen Akademisk Forlag, 263295.

Galtung, J. (2002) 'Peace Journalism - A Challenge' in Kempf, W. \& Luostarinen, H. (eds.) Journalism and the New World Order. Studying war and the media. Göteborg: Nordicom, 259-272.

Goldstein, J. (2001) War and Gender. How Gender Shapes the War System and Vice Versa. Cambridge: Cambridge University Press.

Gutman, R. (1994) 'Foreword' in Stiglmayer, A. (ed.) Mass Rape: the War Against Women in BosniaHerzegovina. Lincoln \& London: University of Nebraska Press, ix-xii.

Haabeth, N. (1993) 'Tunge dager i norsk eksil' [Difficult Days in Norwegian Exile] Aftenposten. 08/02/ 1993.

Higate, P. (2003) 'Concluding Thoughts: Looking to the Future', in Higate, P. (ed) Military Masculinities: Identity and the State. Praeger Publishers: Westport, 201-216.

Hopton, J. (2003) 'The State and Military Masculinities' in Higate, P. (ed) Military Masculinities: Identity and the State. Westport: Praeger Publishers, 111-124. 
Kempf, W. \& Luostarinen, H. (2002) 'Introduction' in Kempf, W. \& Luostarinen, H. (eds.) Journalism and the New World Order. Studying war and the media. Göteborg: Nordicom, 7-13.

Kempf, W. (2002) 'Conflict Coverage and Conflict Escalation' in Kempf, W. \& Luostarinen, H. (eds.). Journalism and the New World Order. Studying War and the Media. Göteborg: Nordicom, 59-72.

Lynch, J. \& McGoldrick, A. (2005) Peace Journalism. Gloucestershire: Hawthorn Press.

Mathismoen, O. (1996) 'Strid om Bosnia-vitne' [Quarrel over Bosnia witness] Aftenposten. 21/05/1996.

Moser, C. \& Clark, F. (eds) (2001) Victims, Perpetrators or Actors? Armed conflict and political violence. London \& New York: Zed Books.

Moser, C. \& Clark, F. (2001) 'Introduction', in Moser, C. \& Clark, F (eds) (2001) Victims, Perpetrators or Actors? Armed conflict and political violence. London \& New York: Zed Books.

Nordstrøm, M. (1996) 'Grufull serbisk fangeleir' [Horrifying Serbian Camp] Aftenposten. 24/05/1996.

NTB/DPA (2001) 'SFOR- soldater mistenkt for voldtekt' [NATO- soldiers suspected for Rape] Aftenposten. $16 / 06 / 2001$.

NTB/REUTER/AP (1993) 'Sinnslidende våpen i Bosnia' [Mental Patients as Weapon in Bosnia] Aftenposten Aften. 19/11/1993.

Seifert, R. (1994) 'War and Rape: A Preliminary Analysis' in Stiglmayer, A. (ed.) Mass Rape: the War Against Women in Bosnia- Herzegovina. University of Nebraska Press: Lincoln \& London, 54-72.

Skjelsbæk, I. (2001) 'Is Femininity Inherently Peaceful?' in Skjelsbæk, I. \& Smith, D. Gender, Peace and Conflict. London: Sage Publications, 47-67.

Skjelsbæk, I. (1997a) Gendered Battlefields. A Gender Analysis of Peace and Conflict. PRIO Report 6/97. Oslo:.PRIO.

Skjelsbæk, I. (1997b) ‘Abnorme individer eller abnorme situasjoner?’ [Abnormal Individuals or Abnormal Circumstances?] Aftenposten. 14/08/1997.

Stiglmayer, A. (ed.) (1994) Mass Rape: the War Against Women in Bosnia- Herzegovina. University of Nebraska Press: Lincoln \& London, 54-72.

Tickner, J. (1992) Gender in International Relations. Feminist Perspectives on Achieving Global Security. Columbia. New York:.University Press.

von der Lippe, B. (1999) Metaforens Potens: Essays. Oslo: Forlaget oktober.

Weber, R. (1990) Basic Content Analysis. 2nd ed. Newbury Park, London \& New Delhi: Sage Publications:

Zarkov, D. (2001) 'The Body of the Other Man: Sexual Violence and the Construction of Masculinity, Sexuality and Ethnicity in the Croatian Media' in Moser, C. \& Clark, F. (eds) (2001) Victims, Perpetrators or Actors? Armed conflict and political violence. London \& New York: Zed Books.

ANETTE BRINGEDAL HOUGE, M.A., Peace and Conflict Studies, Department of Political Science, University of Oslo, anette.bringedal.houge@gmail.com 